\title{
Major Animal Health Constraints of Market Oriented Livestock Development in Sidama Dale District Southern Region Ethiopia
}

\author{
Abdulhakim Albe ${ }^{1}$, Teka Feyera ${ }^{1}$ and Kefyalew Gebeyew ${ }^{2 *}$
}

${ }^{1}$ College of Veterinary Medicine, Jigjiga University, Jigjiga, Ethiopia

${ }^{2}$ College of Dry Land Agriculture, Department of Animal and Range Science, Jijiga University, Ethiopia

\begin{abstract}
Background: Knowing the status of major problems that constrain livestock development no doubt contributes to initiating projects that can help improve productivity and market success of Ethiopian farmers; aiming at contributing to reduction in poverty of the rural poor through market oriented agricultural development. The objective of this study is to characterize the livestock production system and investigating the major livestock health problems in the area.

Methodology: Purposive sampling method was used to select 60 households from four peasant association (PA). A structured questionnaire was prepared and the heads of selected households were interviewed to collect data on production system characteristics and the importance of livestock health problems. Focus group discussion was also made with key respondents from each PA and the participants described the major husbandry problems in their area.

Results: The results revealed that mixed crop-livestock production system is the predominant system and animals are kept in very limited grazing land. The livestock herd was dominated by poultry $(36.4 \%)$, goat $(19.51 \%)$, sheep $(19.13 \%)$ and cattle $(18.94 \%)$ while the cattle herd was dominated by cows $(39.27 \%)$ and oxen $(12.87 \%)$. The main roles of poultry in the area are for egg production $(43.79 \%)$, sale $(29.76 \%)$ and meat production $(26.43 \%)$. The main role of cattle in the farming system is as a source of traction power $(41.7 \%)$ for crop production while small ruminants as source of income $(100 \%)$. Equines were used as pack and transport animals. The livestock feeding was mainly based on natural pasture (100\%). In cattle; blackleg, mastitis, Lumpy Skin Disease (LSD) and calf diarrhea were the most important diseases. Ectoparasite and GIT parasitosis were the most important diseases in small ruminants. Colic and respiratory problems were considered important in equine. In poultry, Newcastle disease was the most devastating disease. Most of the respondents complained that animal feed followed by water shortage is serious problem in the livestock sector. Modern veterinary medicaments $(95 \%)$ were known and used by most of the farmers, but traditional medicines were also used to a considerable extent $(5 \%)$.
\end{abstract}

Conclusion: Emphasis should be given in the animal health delivery to maximize health service coverage of the area and Detail epidemiological studies on major economically important diseases of livestock is recommended to be under taken.

Keywords: Animal; Health; Constraints; Livestock; Dale; Survey

\section{Introduction}

Livestock in the Greater Horn of Africa is vital resource in promoting development. They provide $20-30 \%$ of the Gross Domestic Product (GDP), and at the farmer level as much as $70 \%$ of cash income is generated from livestock [1]. Livestock are used by humans to provide a wide range of products and services. Foods derived from animals are important source of nutrients [2] that provide a critical supplement and diversity to staple plant-based diets [3,4].

Ethiopia has one of the largest livestock population in Africa with the estimated domestic animal number of 52.13 million cattle, 24.2 million sheep, 22.6 million goat, 2.5 million camels, 44.89 million poultry, 1.96 million horses, 0.37 million mules and 6.4 million donkeys [5]. Ethiopia's great livestock potential is not properly exploited due to different factors such as traditional management system, limited genetic potential, lack of appropriate disease control policy and lack of appropriate veterinary services [6]. Animal diseases are considered as a major health problem and cause a significant economic loss in countries where livestock production is an important segment of the agricultural practice [7].

Infectious animal diseases that are endemic, or common in a region, generate a variety of significant adverse economic consequences. Most directly, mortality, morbidity, barrenness, and miscarriage in production animals reduce technical efficiency. Costly treatments and altered management practices to ameliorate these losses also reduce profitability [8]. Diseases have numerous negative impacts on productivity and fertility of herds (losses due to mortality and morbidity, loss of weight, depressed growth, poor fertility performance, decrease physical power and the likes [9]. Thus, knowing the status of major problems that constrain livestock development no doubt contributes to initiating projects that can help improve productivity and market success of Ethiopian farmers; aiming at contributing to reduction in poverty of the rural poor through market oriented agricultural development [10]. Therefore, this research intended to characterize the livestock production system in the selected peasant associations of the Dale Districts and to provide baseline information on the major animal health constraints that contribute to poor livestock productivity in the area.

*Corresponding author: Kefyalew Gebeyew, Lecturer, College of Dry Land Agriculture, Department of Animal and Range Science, Jijiga University, PO Box 1020, Jijiga, Ethiopia, Tel: +251931906414; E-mail: kefyalewgebeyew@yahoo.com

Received December 30, 2015; Accepted June 24, 2016; Published June 29 2016

Citation: Albe A, Feyera A, Gebeyew K (2016) Major Animal Health Constraints of Market Oriented Livestock Development in Sidama Dale District Southern Region Ethiopia. J Vet Sci Technol 7: 355. doi:10.4172/2157-7579.1000355

Copyright: (c) 2016 Albe A, et al. This is an open-access article distributed unde the terms of the Creative Commons Attribution License, which permits unrestricted use, distribution, and reproduction in any medium, provided the original author and source are credited. 


\section{Materials and Methods}

\section{Description of study area}

The study was conducted in Dale District which is located between $6^{\circ} 27^{\prime} 00^{\prime \prime}-6^{\circ} 51^{\prime} 00^{\prime \prime} \mathrm{N}$ latitude and $38^{\circ} 00^{\prime} 00^{\prime \prime}-38^{\circ} 37^{\prime} 00^{\prime \prime} \mathrm{E}$ longitude in Sidama Zone, Southern Nations Nationalities and Peoples (SNNP) Regional State of Ethiopia. This District is one of the 21 District in the Zone covering a total area of $1,494.63 \mathrm{~km}^{2}$ with the altitude range of $1100 \mathrm{~m}$ to $2650 \mathrm{~m}$ (from low lands in the west to the highlands in the east) and at about of $320 \mathrm{~km}$ south of Addis Ababa [11]. The main livestock species in the District are cattle, goats and sheep. The livestock resources are cattle - 225,698 (82,666 local cows and 1584 crossbred dairy animals, $80 \%$ are in urban and peri-urban areas); sheep - 30,152; Goats - 31,443; Poultry - 218,923; Horses - 2,498; Mules - 431; Donkeys - 16,321; Beehives - 10,949.

\section{Study protocol}

Sampling procedure and sample size: A purposive selection method has been done to select the peasant associations based on accessibility to transport and difference in geographical location. Accordingly, four peasant associations (PAs) namely; Arada, gejaba, Mesincho and Shefin were purposely selected as study sites. From each PA 15 households were randomly selected which then made a total of 60 households to be included in the study. All livestock (Cattle, sheep, goat, equine) and poultry owned by selected respondents were considered as study animals, consequently, there were a total of 1597 animals sampled constituting 303 cattle, 312 goats, 306 sheep, and 91 equine and 585 poultry.

\section{Data collection}

Questionnaire survey: A detailed questionnaire was designed to generate information related to animal production (demographic features of respondents and their land use pattern, livestock herd size, livestock function, feeding practice and availability, management systems such as watering, housing, breeding and record keeping, labor use and livestock marketing) with particular emphasis on major livestock health problems in the area and measures taken by the farmers against livestock diseases and trend of using modern veterinary services. The questionnaire was pretested before its full implementation and adjusted for clarity to shorten the time it takes while administering and minimize recall bias and it was filled directly by interviewing randomly selected farmers from different villages of the four PAs.

\section{Focus group discussion}

The focus group discussion was done with 10 key respondents from each PA identified by PAs development agents. Points considered during the discussion were disease occurrence and trend for the last few years and constraints of livestock production. The major livestock problems such as major diseases, major feed types in the area, and other issues on livestock production have been raised for discussion to collect basic information. Consultation of the District veterinary professional to identify the major livestock health problems in their area and about the health services coverage of the District. The cases were classified by species in to diseases affecting cattle, goat, sheep and equine.

\section{Data analysis}

The data collected were entered in to MS-Excel 2000 computer program. The analysis and summarization of the data was made using simple descriptive statistics.

\section{Results}

\section{Demographic and land holding features of respondents}

Demographic feature of respondents showed that most of the interviewees $(81.7 \%)$ were male and the rest female $(18.3 \%)$. Their educational back ground indicated that $56.7 \%(n=34)$ were literate, $33.4 \%(\mathrm{n}=20)$ are primary school, $23.3 \%(\mathrm{n}=14)$ are secondary school and above, 20\% $(\mathrm{n}=12)$ had illiterate knowledge and $23.3 \%(\mathrm{n}=14)$ had religious knowledge (Table 1). Respondent's family size proportion showed 158 (44.8\%) and 194 (55.2\%) have family members less or equal to 15 years of age and greater than 15 years of age, respectively. The average family size was 5.87 persons from which more than half $(55.2 \%)$ was above 15 years old.

The vast majority (90\%) and majority of the farmers (73.3\%) had their own crop land and grazing land, respectively. The average total land size owned by households was 1 ha and about $90 \%$ of the respondents had their own crop land where as some $6.7 \%$ of the respondent's uses ranted cropland. On the other hand, average crop and grazing land per household were 0.8183 and 0.125 ha respectively. The average privately owned crop land size was 0.016 ha and none of them owned private grazing land at all (Table 2).

\section{Livestock inventory and composition}

The average herd size and composition of cattle, sheep, goats, equines and poultry per households' are presented in Table 3. Poultry comprise the largest proportion of the livestock herd $(\mathrm{n}=585,36.4 \%)$, and followed by goat $(n=312,19.51 \%)$, Sheep $(n=306,19.13 \%)$, cattle $(n=303,18.94 \%)$, lastly Equines ( $n=91,5.67 \%)$ in their order of appearance. Cows $(39.27 \%)$ dominate the most shares of cattle herd size followed by calves (24.3\%). In the case of sheep and goats, the flock is comprised primarily of ewe and doe respectively. In goats doe's represent 102 (32.6\%) and in Sheep ewe's proportion were 99 (32.3\%). The equine herd is very much dominated by donkeys taking $70.32 \%$ of the share of which mature male donkeys are the predominant ones $57.8 \%$.

\section{Purpose of keeping livestock}

The most important product of cattle was milk (100\%). There were also households producing meat (46.7\%), and hides (20\%) from cattle. Milk was consumed as raw by $80 \%$ of the respondents and regarding

\begin{tabular}{|c|c|c|c|}
\hline Variable & N & Category & $\begin{array}{c}\text { Frequency } \\
\text { (Proportion) }\end{array}$ \\
\hline \multirow{2}{*}{ Sex } & \multirow{2}{*}{60} & Male & 81.7 \\
\hline \multirow{2}{*}{$\begin{array}{c}\text { Educational } \\
\text { Status }\end{array}$} & \multirow{2}{*}{60} & Female & 18.3 \\
\hline & & Illiterate & 20.0 \\
\hline & & Religious & 23.3 \\
\hline \multirow{2}{*}{ Family size } & \multirow{2}{*}{60} & Literate & 56.7 \\
\hline & & primary school & $33.4 \%$ \\
\hline
\end{tabular}

Table 1: Demographic and land holding features of respondents.

\begin{tabular}{|c|c|c|c|}
\hline Land use pattern & Mean & Minimum & Maximum \\
\hline Cropland owned (ha) & 1.1 & $4(0.2$ ha $)$ & $3(2 \mathrm{ha})$ \\
\hline Crop land contracted (ha) & 0.5 & $56(0 \mathrm{ha})$ & $4(1 \mathrm{ha})$ \\
\hline Fallow land owned (ha) & 0.15 & $10(0.1 \mathrm{ha})$ & $7(0.2 \mathrm{ha})$ \\
\hline Grazing land owned (ha) & 0.3 & $13(0.1 \mathrm{ha})$ & $5(0.5 \mathrm{ha})$ \\
\hline Total (ha) & 2.05 & & \\
\hline
\end{tabular}

Table 2: Mean maximum and minimum values of land holdings in the sampled households. 


\begin{tabular}{|c|c|c|c|c|c|c|c|}
\hline$\checkmark$ & & Number & Range & Minimum & Maximum & $\begin{array}{l}\text { Proportion from } \\
\text { livestock herd }\end{array}$ & $\begin{array}{c}\text { Proportion from species } \\
\text { herd }\end{array}$ \\
\hline \multicolumn{2}{|r|}{ cattle } & & & & & & $N=303$ \\
\hline$\checkmark$ & Calve male & 26 & 1 & 1 & 2 & 1.62 & 8.5 \\
\hline$\checkmark$ & Calve female & 48 & 2 & 1 & 3 & 3.00 & 15.8 \\
\hline$\checkmark$ & Heifers & 32 & 3 & 1 & 4 & 2.00 & 10.5 \\
\hline$\checkmark$ & Dry cow & 38 & 3 & 1 & 4 & 2.37 & 12.5 \\
\hline$\checkmark$ & lact. cow & 81 & 3 & 1 & 4 & 5.07 & 26.7 \\
\hline$\checkmark$ & Oxen & 39 & 1 & 1 & 2 & 2.44 & 12.8 \\
\hline$\checkmark$ & Bulls & 39 & 1 & 1 & 2 & 2.44 & 12.8 \\
\hline \multicolumn{2}{|r|}{ Goat } & & & & & & $N=312$ \\
\hline$\checkmark$ & Kid male & 21 & 1 & 1 & 2 & 1.31 & 6.7 \\
\hline$\checkmark$ & Kid female & 17 & 2 & 1 & 3 & 1.06 & 5.4 \\
\hline$\checkmark$ & Yearling & 46 & 2 & 1 & 3 & 2.88 & 14.7 \\
\hline$\checkmark$ & Doe & 102 & 4 & 1 & 5 & 6.38 & 32.6 \\
\hline$\checkmark$ & Goat castrated & 24 & 2 & 1 & 3 & 1.50 & 7.6 \\
\hline$\checkmark$ & Buck & 102 & 4 & 1 & 5 & 6.38 & 32.6 \\
\hline \multicolumn{2}{|r|}{ Sheep } & & & & & & $N=306$ \\
\hline$\checkmark$ & Lamb male & 24 & 2 & 1 & 3 & 1.50 & 7.8 \\
\hline$\checkmark$ & Lamb female & 27 & 1 & 1 & 2 & 1.69 & 8.8 \\
\hline$\checkmark$ & Yearling & 49 & 1 & 1 & 2 & 3.06 & 16.0 \\
\hline$\checkmark$ & Ewe & 99 & 3 & 1 & 4 & 6.19 & 32.3 \\
\hline$\checkmark$ & Sheep castrated & 14 & 1 & 1 & 2 & 0.87 & 4.5 \\
\hline$\checkmark$ & Ram & 93 & 3 & 1 & 4 & 5.82 & 30.3 \\
\hline \multicolumn{2}{|r|}{ Donkey } & & & & & & $N=64$ \\
\hline$\checkmark$ & Young donkey & 18 & 1 & 1 & 2 & 1.12 & 28.1 \\
\hline$\checkmark$ & Mature female donkey & 9 & 0 & 1 & 1 & 0.56 & 14.0 \\
\hline$\checkmark$ & Mature male donkey & 37 & 1 & 1 & 2 & 2.31 & 57.8 \\
\hline \multicolumn{2}{|r|}{ Horse } & & & & & & $\mathrm{N}=27$ \\
\hline$\checkmark$ & Young horse & 5 & 1 & 1 & 2 & 0.31 & 18.5 \\
\hline$\checkmark$ & Mature female horse & 1 & 0 & 1 & 1 & 0.06 & 3.7 \\
\hline$\checkmark$ & Mature male horse & 21 & 1 & 1 & 2 & 1.31 & 77.7 \\
\hline \multicolumn{2}{|r|}{ Poultry } & & & & & & $N=585$ \\
\hline$\checkmark$ & Young & 236 & 19 & 1 & 20 & 14.7 & 40.3 \\
\hline$\checkmark$ & Mature female & 183 & 5 & 1 & 6 & 11.4 & 31.2 \\
\hline$\checkmark$ & Mature male & 166 & 5 & 1 & 6 & 10.3 & 28.3 \\
\hline
\end{tabular}

Table 3: Herd size of livestock per household.

meat, $19.7 \%$ consumed raw form. Most of the households consumed egg in boiled/cooked form (91.7\%) and $8.3 \%$ of the respondents consumed raw. The most important purpose of cattle was provision of traction power (41.7\%). Goats (85\%) and sheep (86.7\%) were kept for sale and meat production (58.3\%) and (56.7\%) for both goats and sheep respectively. Donkeys were kept solely for loading (100\%) and horses for transportation (100\%) purposes.

\section{Livestock management}

Housing: Some of the respondents (10\%) house comprises different species of animals within one house, which is separated from their own (main) house; and $90 \%$ of the respondent's house comprises the same species of animals in different houses, which are separated their own (main) home. Regarding breeding, most of the respondents $(73.3 \%)$ use uncontrolled natural mating and only $26.7 \%$ of the respondents use selected bulls (controlled natural breeding) to reproduce cattle.

Water source: In the study site, they have water sources for watering animal like rivers, streams, ponds and well. Majority of the livestock water source were river (40.2\%), well (27.3\%), stream (18\%), and pond (14.3\%). These water sources are not available throughout the year. They encounter shortage of water mostly during the dry season especially from January to March (winter) seasons.

\section{Feed resources and feeding practices}

Natural pasture (100\%) and Stover (65\%) were the most frequently used feed resources in the study area. The respondents also reported that feed availability depends on seasons. Feed shortage is the main problem especially during dry season in the study area to maintain market oriented livestock development extension. Natural pasture was more available in the wet season (100\%). Most of the farmers supplement livestock with minerals (51.7\%) and availability of minerals is most of the time during the wet season about (95\%) (Table 4). Among the interviewed farmers, $23.3 \%$ had communal grazing land and $(73.3 \%)$ of interviewed farmers used grazing land on year round basis.

\section{Livestock culling criteria and disposal of cadaver and abortion materials}

The most common reasons of culling livestock mentioned by farmers were poor productivity (33.3\%), old age (25.5\%), diseased (22\%) and infertility (19.1\%) were also mentioned by farmers. Majority of the respondents $(77.7 \%)$ said that dead animals, after birth fluids and aborts were simply thrown away in the nature. Giving to scavenger animals (dogs and hyena) (13.3\%) also mentioned as a disposing means, and burring (9\%) to some extent. 


\begin{tabular}{|c|c|c|c|}
\hline \multirow{2}{*}{ Feed resource } & $\begin{array}{c}\text { Frequency } \\
\text { (Proportion) of } \\
\text { farmers }\end{array}$ & \multicolumn{2}{|c|}{ Availability } \\
\cline { 3 - 4 } & $100(60)$ & Dry season & Wet season \\
\hline Natural pasture & $65(39)$ & $18.3(11)$ & $100(60)$ \\
\hline Stover & $81.7(49)$ & $16.7(10)$ & $81.7(49)$ \\
\hline Cultivated pasture & $51.7(31)$ & $5(3)$ & $95(50)$ \\
\hline Minerals & $57.3(50)$ \\
\hline
\end{tabular}

Table 4: Major livestock feed resources in the study areas.

\section{Health problems identified by respondents at survey}

The information generated through the questionnaire survey and focus group discussion indicated that diseases are one of the most important limiting factors of livestock keeping in the area. They also indicated that the disease dynamics is aggravated by many factors like, inadequate veterinary service, season, agro-ecological and minimum attention to animal health by government and non-government bodies. Scarcity and shortage of livestock feed are also known to be limiting factors to animal production by making animals unproductive and susceptible to many diseases. Livestock owners were asked to describe five important diseases, which affect animal species in the study area (cattle, sheep, goats and equines) and prioritize them based on their relative degree of importance. Respondents described diseases in their local names (Table 5). These local names were given their veterinary equivalent name based on, the symptoms mentioned and discussions with veterinarians in the area. According to the District animal health professionals, the main problems affecting the livestock keeping in order of appearance is shortage of feed/ grazing land, water shortage and diseases respectively. Lack of transport followed by lack of drugs and vaccines are the major problems faced in the treatment of livestock and the drugs that are available are costly in the District because of that owners use traditional healers. Furthermore, the respondents reflected that they need to have the knowledge how to improve feed shortage, e.g., using cultivated pasture and they had comments like, the drug that the animal health professional use privately is not the correct drug, but drug like soft drinks.

\section{Occurrence of abortion in the last two years}

About $38.3 \%$ of the farmers encountered abortion in the past two years. The most frequent abortion occurred in bovine (39.1\%), caprine (26.1\%) and ovine (34.7\%). Mostly abortions occurred in early and late gestation period. The season's encountered abortions are autumn and summer

\section{Control measures against livestock diseases}

Although the majority of the farmers on the study area have access to modern veterinary service (95\%), a considerable proportion of respondents, $48.3 \%$, use traditional healer for many different abnormalities, and diseases conditions such as infectious diseases, parasitic diseases and non-infectious cases. From the proportion of respondents who use traditional healer, infectious cases (51.7\%) are the most treated using traditional medicament followed by parasitic cases (48.22\%). Modern treatment is given in the Yirgalem veterinary clinic at Yirgalem town; there was no other private veterinary clinic in the area and there were only private drug shops. From the proportion of respondents who use modern veterinary services, $40.32 \%$ mentioned transport/ distance to the veterinary clinic as a main problem faced when they want to treat or vaccinate their animals. Drugs and vaccine shortage and Lack of modern clinical services were mentioned by $41.86 \%$, and $17.81 \%$ of the respondents respectively.

\section{Veterinary service}

$95 \%$ of the respondents have an access to modern veterinary service and $5 \%$ have no access to modern veterinary service. Cost of treatment and vaccination and proportion of respondents is described in Table 6 . The survey also indicated that $31.7 \%(\mathrm{~N}=19)$ of the respondents reported to the government body when outbreak/diseases were encountered.

\section{Discussion}

\section{Characteristics of the livestock production system}

This survey showed that mixed-livestock production is the most practiced production system in the area. Shortage of land is mentioned to be one of the constraints for the livestock development in the area, since food crop cultivation is given first priority. Poultry are the dominant livestock species present in the area. Cattle, Sheep and goats also comprised a good proportion of the livestock species. The farmers kept cattle mostly for milk, meat and traction power although the yield of the local cattle is not significant, which is not exceeding the house hold consumption according to Ref. [12]. Use of local bulls for breeding is the primary option for most farmers (73.33\%). This figure is more or less similar to the survey report of Ref. [12], conducted in Alaba District which reported that $75 \%$ use local bulls for breeding. This may be attributed to shortage of AI service coverage in the area. Based on the result of this study livestock diseases and their consequences have severe impact on the small holder farmers' livelihood directly and indirectly. Animal diseases have also been indicated as public health hazards [13]. It is also indicated that major constraints to alleviate animal health problems include low quality and inadequate animal health services, minimum attention to the services, low and/or no private sector involvement, moreover, the animal health of the District is also exacerbated by different factors like feed and water shortage, poor management, dirty water, traditional treatment practices.

\section{Animal health problems}

Cattle: Black leg was one of the most mentioned infections of cattle's as described in the in Table 5. All of the respondents describe black leg to affect all age and sex groups of cattle except calves. Although the degree varies as found in heifer, cows and bulls as found in this study. This is consistent with that described by Radostits et al. [14] regarding the diseases incidence that is high when calves reach the susceptible age group which is largely confined to young stock between the age of 6 months and 2 years. Black leg was also reported to be the most important infectious diseases with a prevalence rate of $20 \%$ in the north part of Ethiopia by Leggess [15]. Furthermore the diseases were claimed to be the leading cattle health problem together with anthrax in Ginchi water shade areas as reported by Eshete et al. [16].

Mastitis was also the second most important disease affecting cows as mentioned by $33.33 \%$ of the interviewed farmers. Cows are at risk of acquiring mastitis when there is improper milking and poor udder health management like preventing teat from lesion causing agent like tick infestation [17]. Mastitis was one of the most economically important multi-causal infections of cows in the study area. Mastitis is economically the single most important diseases of the dairy cattle. It reduces milk yields, profit and the quality of milk and milk products in all dairy producing countries of the world and premature culling [18]. There is also culling due to diseases caused low production (milk); that was described by Mungube [19] who reported annual mastitis culling rate of $7.23 \%$ due to milk loss.

The result of this study revealed that Lumpy Skin Disease (LSD) was the most mentioned skin disease by respondents. Especially in 


\begin{tabular}{|c|c|c|c|c|c|c|c|}
\hline \multirow[t]{2}{*}{ Name of the disease } & \multirow[t]{2}{*}{ Local name } & \multicolumn{5}{|c|}{ No of farmers described the disease as } & \multirow[t]{2}{*}{ Overall Rank } \\
\hline & & $1^{\text {st }}$ & $2^{\text {nd }}$ & $3^{\text {rd }}$ & $4^{\text {th }}$ & $5^{\text {th }}$ & \\
\hline \multicolumn{8}{|l|}{ Calves } \\
\hline - Calf diarrhoea & Siittu deeo & 25 & 20 & 6 & 4 & 5 & 1 \\
\hline - Black leg & Lammootta & 17 & 31 & 6 & 3 & 3 & 2 \\
\hline - Mite & Bijajo & 9 & 15 & 26 & 8 & 2 & 3 \\
\hline \multicolumn{8}{|l|}{ Cow } \\
\hline - Black leg & Lammootta & 21 & 17 & 9 & 7 & 6 & 1 \\
\hline - Mastitis & Gadansa & 20 & 19 & 21 & 0 & 0 & 2 \\
\hline - LSD & Qada & 19 & 31 & 4 & 3 & 3 & 3 \\
\hline \multicolumn{8}{|l|}{ Ox } \\
\hline - Black leg & Lammootta & 24 & 16 & 12 & 6 & 2 & 1 \\
\hline - LSD & Qada & 26 & 15 & 10 & 9 & 0 & 2 \\
\hline - Tick infestation & Deere & 10 & 30 & 17 & 3 & 0 & 3 \\
\hline \multicolumn{8}{|l|}{ Shoat } \\
\hline - Ectoparasite & Gobbayidi irkiraano & 30 & 15 & 8 & 5 & 2 & 1 \\
\hline - GIT parasite & Godowu gido irkirano & 19 & 31 & 6 & 3 & 1 & 2 \\
\hline - Respiratory problem & Folate amanyoti qara & 11 & 29 & 13 & 5 & 2 & 3 \\
\hline \multicolumn{8}{|l|}{ Equine } \\
\hline - Wound & Mada & 27 & 23 & 6 & 4 & 0 & 1 \\
\hline - Colic & Game & 22 & 17 & 15 & 3 & 3 & 2 \\
\hline - Respiratory problem & Folate amanyoti qara & 11 & 20 & 14 & 9 & 6 & 3 \\
\hline
\end{tabular}

Table 5: Major diseases of livestock mentioned by sampled farmers.

\begin{tabular}{|c|c|c|c|c|}
\hline \multirow{2}{*}{ Degree of cost } & \multicolumn{2}{|c|}{ Treatment } & \multicolumn{2}{c|}{ Vaccination } \\
\cline { 2 - 5 } & Frequency & Percentage & Frequency & Percentage \\
\hline Expensive & 28 & 46.7 & 19 & 31.7 \\
\hline Moderate & 27 & 45.0 & 36 & 60.0 \\
\hline Cheap & 5 & 8.3 & 5 & 8.3 \\
\hline
\end{tabular}

Table 6: Response to cost of treatment and vaccination at the study area.

cow, (16\%) has got the third diseases affecting cows. This is followed by in heifer (15\%) which has got the third rank from the list of diseases affecting heifer groups [20]. Also report similar result (7\%) incidence in Yerer water shade, Adaliben District. The disease is known to affect the body condition and work output of the affected cattle and decreased milk yield as indicated by different authors [14,17]. All age groups (except calves) and both sex are mentioned by respondents in this study to be affected by LSD.

In the present study, calf diarrhea is mentioned by farmers as a serious health problem affecting calf. Calves could be infected by environmental bacteria such as Eshershicia coli, Salmonella species as well as virus like Rota virus, Corona virus, and feed change. The importance of calf diarrhea was also reported by previous authors [21]. Several factors affect the health and vigor of calf in the early period of calf hood. Among these factors inadequate feeding of colostrums, farm hygiene and environmental conditions are the most important.

\section{Sheep and goat}

Parasitic diseases in small ruminants were found to be high which was responded by the farmers during interview and contact of veterinary professional. Among the parasitic diseases, endoparastic infestation comprises more than half of the reported cases. This could be attributed to overgrazing of infested pasture and low use of antihelmenthics. Which also agrees (15\%) with the report of Abraha [22].

In sheep and goats, respiratory problems which is characterized by nasal discharge and coughing and subsequently death in some cases was mentioned by farmer as the first most important disease. The same result was reported by Mekonnen [23] in Arsi highlands. The clinical signs are suggestive of pasteurellosis which are in agreement with the signs of pasteurellosis described by Gilmour [24].

\section{Equine}

Wounds are amongst one of the commonest health concerns to afflict working donkeys in many countries [25]. In addition, the study on donkey in Ethiopia has demonstrated that back sores and wounds are the most commonly observed health problem. Unfortunately, carts, wounds, punctures and lacerations are a fact of life when one has mules and donkeys. The potential cause of equine wounds are almost endless: punctures from sharp object like metal and glass; shear wounds from barbed wire sticks; collusion injuries from falling or running in to the object and entrapment, such as getting a leg hung up in a rope or in a cattle are major cause of injury [26].

Wounds in working donkeys are seen on the leg, girth, tail, saddle and wither regions [26]. These wounds are often caused by a combination of poorly fitting and designed tack or harnesses, beating with sticks and improper management practices. One approach to decrease the prevalence of wounds is through educations of donkey users. Ethiopian farmers have themselves identified a need for greater knowledge through training [27].

Colic (abdominal pain) is an important and frequently occurring disease in the area according to the respondents both in the group discussion and questionnaire survey. All owners of equines listed this disease problem as the second most important. This is attributed to poor management, especially poor care of the teeth, heavy infestation rate of houses with the red worms, restricted access to water, feeding of equine with feeds that their intestine is not able to digest. The causes of this disease sign are numerous in number among these are impaction [28], spasmodic colic, intussusceptions, vulvulus torsion, strangulation, tympany, colitis and verminous cases. The third important equine health problem in this study was respiratory disease complex. Three to eight percent incidence rate of respiratory disease complex was reported by Rose [28].

The first most important equine health problem causing death and decreased work output in this study was respiratory disease complex. $3-8 \%$ incidence rate of respiratory disease complex was reported by Rose [28]. In another study in central Ethiopia, 57\% and 43\% incidence rates were reported for males and females, respectively [29]. It could be associated with high temperature and aridity of some parts of the District. 
Citation: Albe A, Feyera A, Gebeyew K (2016) Major Animal Health Constraints of Market Oriented Livestock Development in Sidama Dale District Southern Region Ethiopia. J Vet Sci Technol 7: 355. doi:10.4172/2157-7579.1000355

Page 6 of 6

\section{Poultry}

Focus group discussion and interviewees strongly complained that Newcastle disease (NCD) is a very important chicken disease. It was also reported by Dessie [30] that NCD was the single major health constraint which causes heavy mortality and morbidity to village chicken and affects productivity of the system in the country. This could be due to poor hygienic conditions of the backyard raising condition, selling or low attention to treat sick chicken and receive no vaccination at all. Its frequency in the District is related to absence of control and prevention methods to reduce its economic impact. Salmonellosis and coccidiosis were also among the mentioned diseases by veterinary professional in Yirgalem veterinary clinic.

\section{Conclusion}

Diseases and feed shortage were the problem of livestock development extension programs in the study area. Blackleg, Mastitis, LSD and Calf diarrhea were the most important diseases of cattle. Wound, colic and respiratory disease complex were considered as the most important constraints of equine health. Modern veterinary medicaments were known and used by most of the farmers, but traditional medicines were also used to a significant extent. Therefore, Emphasis should be given in the animal health delivery to maximize health service coverage of the area. Livestock owners must receive basic training regarding animal diseases prevention, modern techniques in animal husbandry and management skills which can fit to the local situation, and Detail epidemiological survey on major economically important diseases of livestock is recommended to be under taken.

\section{Competing Interest}

The authors declare that they have no competing interest.

\section{Authors' Contributions}

AA conceived the study, designed and conducted all laboratory experiments analyzed and interpreted experimental results. TF and KG participated in the proposal, study design and manuscript preparations. All authors read and approved the final manuscript.

\section{Acknowledgements}

The author's heart fully appreciation is to Jigjiga University for funding the cost of research work. Most truthful thanks go to all my friends and family, Sidama District Agriculture office staffs for their valuable assistance during data collection work of this study.

\section{References}

1. Ndikima S, Suth J, Kamadi R, Ossera S, Marambi R, et al. (2000) Coping mechanisms and their efficiency in disaster-prone pastoral system of greater horn of Africa. Effect of the 1995-1997 draught and the 1997-1998 ELNINO rains and response of pastorals and livestock. International Livestock research Institute (ILRI), Nairobi, Kenya. pp: 2-4.

2. Givens DI (2010) Milk and meat in our diet: good or bad for health? Animal 4: 1941-1952.

3. Murphey SP, Allen LH (2003) Nutritional importance of animal source foods. J Nutr 133: 3893-3897.

4. Randolph TF, Schelling E, Grace D, Nicholson CF, Leroy JL, et al. (2007) Invited review: Role of livestock in human nutrition and health for poverty reduction in developing countries. J Anim Sci 85: 2788-2800.

5. Central Statistics Authority (2012) Federal Democratic Republic of Ethiopia Agricultural sample survey on livestock and livestock production (Private peasant holdings), Statistical Bulletin No. 532, Addis Ababa, Ethiopia 2: 9-20.

6. Genet M, Tadesse G, Basaznew B, Mersha C (2012) Pathological Conditions Causing Organ and Carcass Condemnation and Their Financial Losses in Cattle Slaughtered in Gondar, Northwest Ethiopia. Afr J Basic Appl Sci 4: 200-208.
7. Fekadu A, Legesse E, Tesfaye D (2012) The Cause, Rate and Economic Implication of Organ Condemnation Cattle Slaughtered at Jimma Municipal Abattoir, Southwestern Ethiopi. Global Veterinaria 9: 396-400.

8. Bennett R, ljpelaar J (2005) Updated Estimate of the cost Associated with thirty four Endemic Livestock Diseases in Great Britain: A note. J Agric Econ 56 : 135-144.

9. Central Agriculture Census Commission (2003) Ethiopian Agricultural Sample Enumeration, Land Use 2001-2002 (1994 E.C), Addis Ababa, Ethiopia. pp: 29-43.

10. https://ipmsethiopia.wordpress.com/

11. Central Statistics Authority (2003) Ethiopian Agricultural Sample Enumeration, 2001/2002. Southern Nation Nationalities and Peoples Region. Statistical report on livestock and farm implements. Addis Ababa, Ethiopia. pp: 35-43.

12. Mekonnen K (2007) Major animal health problems of market oriented livestock development in Alaba Woreda, Southern Nations Nationalities and people's region. DVM thesis, FVM, Addis Ababa University, Debrezeit, Ethiopia. p: 21.

13. Assegid W (2000) Constraints to livestock and its products in Ethiopia: Policy implications. DVM Thesis, FVM, Addis Ababa University, Debrezeit, Ethiopia.

14. Radostits DM, Blood DC, Gay CC (1994) Veterinary Medicine. A Text book of diseases of cattle, sheep, pigs, goats and horses. 8th edition. London, Bailliere Tindal, pp: 748-785.

15. Leggess G (1996) Livestock Health Conditions in Central Tigray. In: Rura Exploratory Studies Processing of a Workshop. Oyhus AO, Gebru G (eds). Agricultural University of Norwegian (AUN). pp: 85-100.

16. Eshete G, Yami A, Baars R (2002) An assessment of feed resources, thei management and impact on livestock productivity in Ginchi watershed area MSc Thesis Presented to School of Graduate Studies of Haramaya University, Haramaya, Ethiopia.

17. Quinn PJ, Carter ME, Markey B, Carter GR (1994) Clinical veterinary microbiology. Wolfe publishing, London. pp: 175-179.

18. Radostitis OM (2001) Heard health: Food animal production medicine. 3rd edition. WB Saunders Company, USA, pp: 1-45.

19. Mungube E (2001) Management and Economics of dairy cow mastitis in the urban area of Addis Ababa. MSc Thesis, Faculty of Veterinary Medicine, Addis Ababa University, DebreZeit, Ethiopia.

20. Tesfahiwot Z (2004) Major health problems of livestock in the Yerer watershed, Adaliben woreda, South Eastern Shoa, DebreZeit, Ethiopia. DVM Thesis, Faculty of Veterinary Medicine, Addis Ababa University, DebreZeit, Ethiopia.

21. Busato A, Steiner L, Martin SW, Shoukri MM, Gaillard C (1997) Calf health in cow-calf herds in Switzerland. Prev Vet Med 30: 9-22.

22. Abraha G (2007) Major animal health problems of market oriented livestock development in Atsbin Womberta woreda, Tigray Regional State. DVM Thesis, Faculty of Veterinary Medicine, Addis Ababa University, DebreZeit, Ethiopia

23. Mekonnen T (2000) An epidemiological study on ovine pasteurellosis in Arsi, South East Ethiopia. DVM Thesis, Faculty of Veterinary Medicine, Addis Ababa University, DebreZeit, Ethiopia.

24. Gilmour NJL (1993) Pasteurelosis: The Disease. In: Pasteurelosis in Animal Production. ACIAR Proceedings 43: 79-83.

25. Nengomasha E, Jell N, Pearson RA (1995) Phenotypic characteristics of working donkeys in Western Zimbabwe. In: Proceedings of the ATNESA workshop 'Meeting the challenges of animal traction', December 4-8 1995, Karen, Ngong Hills, Kenya.

26. Martin Curran M, Feseha G, Smith DG (2005) The impact of access to anima health services on donkey health and livelihoods in Ethiopia. Trop Anim Health Prod 37 Suppl 1: 47-65.

27. Tesfaye A, Martin Curran M (2005) A longitudinal survey of market donkeys in Ethiopia. Trop Anim Health Prod 37 Suppl 1: 87-100.

28. Rose RJ, Hodgson DR (2000) Manual of equine practice. 2nd edn. WB Saunders, USA, pp: 187-292.

29. Alemnesh W (2004) Investigation in the Occurrence of Strangles in Four Woreda of Central Ethiopia. DVM Thesis, Faculty of Veterinary Medicine, Addis Ababa University, Debrezeit, Ethiopia.

30. Dessie T, Jobre Y (2004) A review of the importance and control of Newcastle disease in Ethiopia. Ethiopian Veterinary Journal 8: 71-81. 